DOI

\title{
ОСОБЛИВОСТІ ВИКЛАДАННЯ ДИСЦИПЛІНИ “ДОМЕДИЧНА ДОПОМОГА В ЕКСТРЕМАЛЬНИХ СИТУАЦІЯХ” ІНОЗЕМНИМ СТУДЕНТАМ
}

О. Б. Сван

\author{
ДВНЗ “Тернопільський державний медичний університет
} імені І. Я. Горбачевського МОЗ України”

\section{PECULIARITIES OF TEACHING THE DISCIPLINE "PRE-MEDICAL AID IN EXPERIMENTAL SITUATIONS” FOR FOREIGN STUDENTS}

\author{
O. B. Svan \\ SHEI “Ternopil State Medical University by I. Ya. Horbachevsky of MPH of Ukraine”
}

\begin{abstract}
Викладання домедичної допомоги в екстремальних умовах для студентів-іноземців повинно відбуватися у спеціалізованих навчальних лабораторіях і вимагає ірунтовного логістичного забезпечення. Заняття повинно проходити у формі виконання типових сценаріїв симульованих невідкладних станів. Кожну навичку викладач спершу показує самостійно, а далі пропонує виконати кожному студенту. Оцінювання відбувається на основі ефективності та якості реалізації студентом сценаріїв $з$ невідкладного стану та тестового контролю.
\end{abstract}

Teaching of pre-medical aid in experimental conditions for foreign students should take place in specialized education laboratories and requires a substantiated logistic supply. Lesson should be held in the form of performance of typical scripts of simulated emergency conditions. Every habit the teacher firstly shows by himself and then propose to do for every student. Evaluation is made on the basis of effectiveness and quality of realization by a student the scripts on emergency condition and test control.

Вступ. Останні події на політичній арені в Україні істотно вплинули на характер вищої медичної освіти. Зокрема, з вересня 2015 року для студентів вищих медичних закладів освіти III-IV рівнів акредитації, які навчаються за спеціальністю 7.110101 “Лікувальна справа”, 7.110104 “Педіатрія”, 7.110105 “Медико-профілактична справа”, впроваджується викладання нової навчальної дисципліни “Домедична допомога в екстремальних ситуаціях”. Це нормативна дисципліна, яка регламентована листом МОЗ України від 24.03.2015 р. № 08.01-47/8986 замість навчальної дисципліни "Медицина надзвичайних ситуацій”. Ї̈̈ вивчення здійснюється впродовж другого року навчання. Кінцевими цілями є: вміти надати домедичну допомогу постраждалим за умов надзвичайних ситуацій мирного часу і в бойових умовах.

Мета роботи - проаналізувати специфіку викладання домедичної допомоги в екстремальних ситуаціях іноземним студентам.

Основна частина. Вивчення структури навчальної дисципліни, тематичний план практичних за-

\footnotetext{
(с) О. Б. Сван
}

нять показав логічну послідовність в опануванні основних прийомів надання домедичної допомоги, зокрема первинного і вторинного обстеження, забезпечення прохідності дихальних шляхів, діагностики і надання допомоги при різних невідкладних станах, в тому числі при застосуванні зброї масового знищення, застосування засобів індивідуального захисту, діагностики і профілактики бойового стресу і т. п. Особливістю практичних занять $€$ детальний розгляд окремих теоретичних положень навчальної дисципліни та формування вмінь шляхом індивідуального багаторазового виконання кожним студентом практичних навичок відповідно до сформульованих завдань, стосовно надання домедичної допомоги. Ще однією характерною рисою навчальної дисципліни є одночасний розгляд невідкладних станів як у мирний час, так і в бойових умовах на одному практичному занятті. Фактично практичні заняття будуються на виконанні окремих сценаріїв, під час яких симулюються невідкладні стани, проводиться обстеження і надається домедична допомога.

Для успішної реалізації навчальної програми перед кафедрою виникають такі завдання: 
1) виділити спеціалізовані приміщення на кожну навчальну групу (до 12 осіб), де будуть проводитися практичні заняття з домедичної допомоги. Вимогою до цих приміщень, як показує наш досвід, $є$ : площа не менше $25 \mathrm{~m}^{2}$ із центральним подіумом не менше 2,5×2,5 м, який застеляється килимовим покриттям для відпрацювання практичних навичок. Зрозуміло, що студенти розташовуються навколо. Це змушує викладача і студентів бути вбраним у спецодяг для роботи на підлозі. Доречним у такій аудиторії є повний комплект мультимедійного супроводу (комп’ютер + телевізор або комп’ютер + мультимедійний проектор + звукові колонки). Прикладом може стати навчальна лабораторія, розгорнута кафедрою медицини катастроф і військової медицини ДВНЗ “Тернопільський державний медичний університет імені І. Я. Горбачевського МОЗ України” (рис. 1);

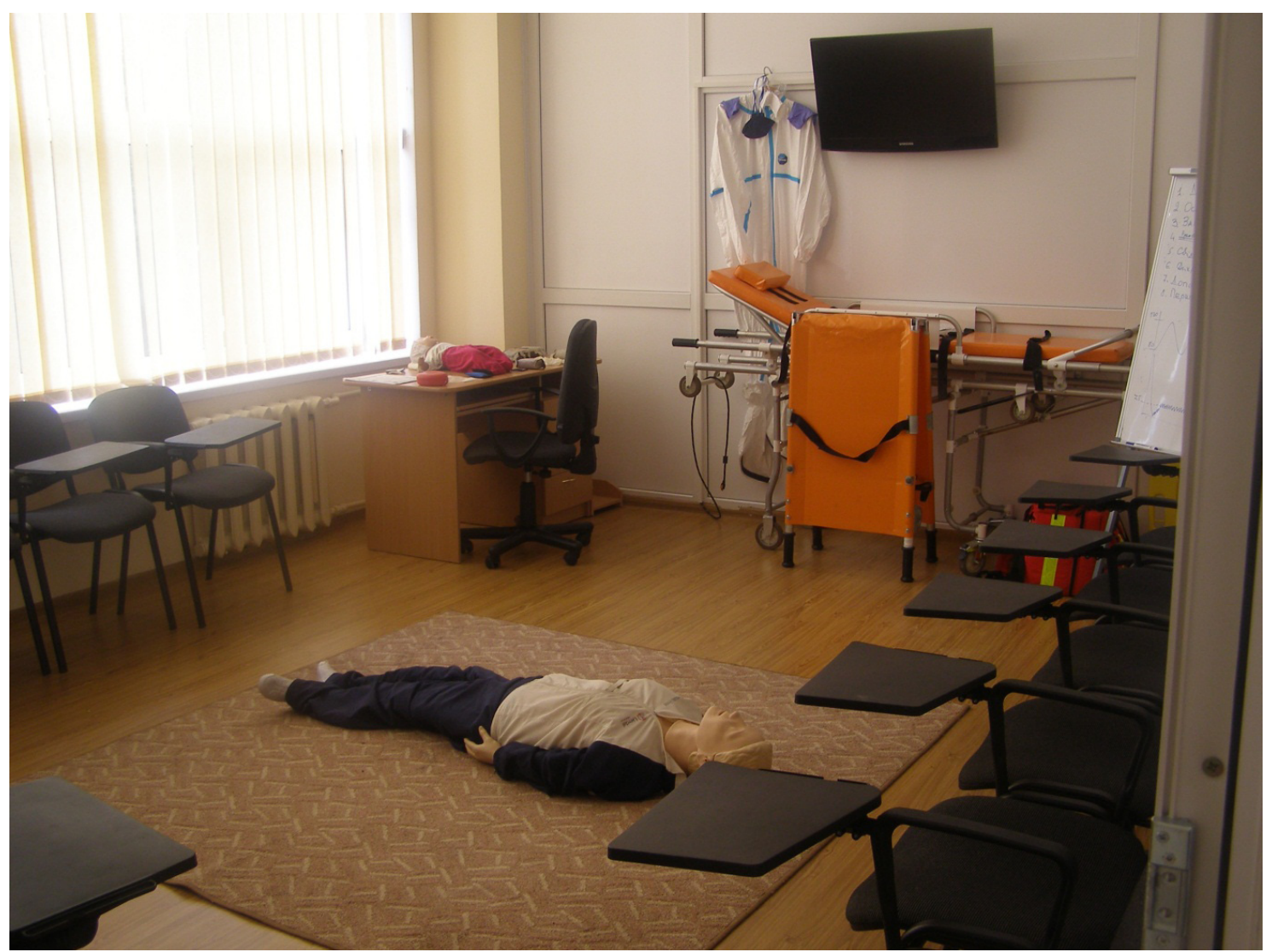

Рис. 1. Навчальна лабораторія з домедичної допомоги кафедри медицини катастроф і військової медицини ДВНЗ “Тернопільський державний медичний університет імені І. Я. Горбачевського МОЗ України”.

2) матеріально-технічне забезпечення навчального процесу: манекени, муляжі, розхідні матеріали. Що стосується домедичної допомоги в бойових умовах, обов'язковими елементами забезпечення студентів є бронежилети, шоломи, тактичні окуляри, макети автоматів та індивідуальні аптечки. Більшість практичних навичок відпрацьовується на симулянті, роль якого виконує хтось із студентів групи;

3) розробка сценаріїв невідкладних станів, які охоплюють весь спектр практичних навичок, передбачених навчальною програмою.

При виконанні цих завдань для забезпечення навчального процесу студентам-іноземцям кафедра може зіткнутися з наступними проблемами. В силу етнічних особливостей та релігійних переконань, студенти-іноземці не з кожної країни зможуть виконувати роль симулянта, що вимагає застосування на практичних заняттях спеціалізованих манекенів. Насамперед це стосується первинного і вторинного обстеження та надання домедичної допомоги при кровотечах і травмах.

По-друге, студенти-іноземці, особливо жіночої статі, не зі всіх країн виявлять бажання опановувати навички надання домедичної допомоги в бойових умовах, коли необхідно працювати на підлозі в бронежилеті та зі зброєю. У зв’язку з цим, пропонується розділити дисципліну на два блоки: 
домедичну допомогу в мирний час та домедичну допомогу в бойових умовах, причому останній блок зменшити до мінімуму в рамках дозволених змін 15 \% основного часу. Доречно вилучити теми 7 “Засоби масового ураження. Домедична допомога” та 9 “Поведінка людей в надзвичайних ситуаціях i бойових умовах. Бойовий стрес: ознаки, профілактика, домедична допомога” Натомість ввести тему “Базова підтримка життєдіяльності (серцеволегенева реанімація і автоматична зовнішня дефібриляція)”, яка входить до всіх європейських і американських навчальних програм для немедичних працівників, проте не передбачена вітчизняною навчальною програмою. Таким чином, навчальна програма з дисципліни “Домедична допомога в екстремальних умовах” для студентів-іноземців може мати такий вигляд.

Тема 1. Принципи надання домедичної допомоги. Первинне і вторинне обстеження (2 год). Поняття про домедичну допомогу. Мета домедичної допомоги. Огляд місця пригоди, забезпечення особистої безпеки, визначення кількості постраждалих і ймовірної причини їх ураження, виклик ШМД та інших рятувальних служб у небезпечній ситуації, залучення випадкових свідків до організації надання домедичної допомоги. Засоби особистої безпеки. Контакт з постраждалим. Правові аспекти надання домедичної допомоги. Визначення рівня свідомості за шкалою APVU. Виклик підмоги. Первинне обстеження постраждалого за методом САВС. Контроль зовнішньої кровотечі. Критерії масивної кровотечі. Забезпечення прохідності дихальних шляхів. Особливості забезпечення прохідності дихальних шляхів при підозрі на ураження голови і шиї. Визначення наявності дихання, його частоти. Оцінка центрального і периферичного пульсу. Правила виклику ШМД. Переведення постраждалого у стабільне положення. Техніка виконання вторинного огляду. Матеріально-технічне забезпечення заняття: манекен (студент-волонтер) для первинного і вторинного обстеження та переведення у стабільне положення, гумові рукавички. Практичні навички: визначення рівня свідомості за шкалою AVPU, визначення масивної кровотечі, забезпечення прохідності дихальних шляхів методом закидання голови і виведення нижньої щелепи (при підозрі на травму голови і шиї), визначення наявності і частоти дихання, визначення наявності і частоти периферичного і центрального пульсу, техніка вторинного обстеження (з голови до ніг), техніка перевертання постраждалого з живота на спину, техніка вкладання постраждалого у стабільне положення на боці.

Тема 2. Порушення прохідності дихальних шляхів (2 год). Анатомо-фізіологічні особливості дихальних шляхів. Причини непрохідності дихальних шляхів. Ознаки повної і часткової непрохідності дихальних шляхів. Техніка забезпечення прохідності дихальних шляхів (закидання голови; виведення нижньої щелепи; введення носо-, ротогорлових трубок). Техніка відновлення прохідності дихальних шляхів при потраплянні стороннього тіла (прийом Геймліха, конікопункція (конікотомія)). Особливості видалення стороннього тіла 3 дихальних шляхів вагітній жінці, огрядній людині, в немовляти. Бар’єрні пристрої для штучної вентиляції легень. Техніка штучної вентиляції легень (рот до рота, рот до носа, рот до лицевої маски, мішком АМБУ). Матеріально-технічне забезпечення заняття: манекен для відновлення прохідності дихальних шляхів і штучної вентиляції легень, манекен для конікотомії, табельні і пристосовані засоби для конікопункції і конікотомії, бар’єрні пристрої (в асортименті) для штучної вентиляції легень рот до рота, мішок АМБУ з комплектом лицевих масок, комплект рото- і носогорлових трубок, манекен новонародженого, гумові рукавички. Практичні навички: діагностика часткової і повної непрохідності дихальних шляхів, забезпечення прохідності дихальних шляхів при наявності стороннього тіла: прийом Геймліха; техніка прийому Геймліха у вагітних жінок і огрядних людей; видалення стороннього тіла у немовляти, техніка забезпечення прохідності дихальних шляхів ротоносогорловою трубками, штучна вентиляція легень методами рот до рота, рот до носа, техніка штучної вентиляції легень методом рот до маски, техніка штучної вентиляції легень мішком АМБУ, техніка конікопункції (конікотомії) тебельними і підручними засобами.

Тема 3. Базова підтримка життєдіяльності (серцево-легенева реанімація і автоматична зовнішня дефібриляція) (4 год). Анатомо-фізіологічні особливості серцево-судинної системи. Причини зупинки серцевої діяльності. Розпізнавання зупинки серцевої діяльності. Показання і техніка серцеволегеневої реанімації дорослого, дитини, немовляти. Техніка використання автоматичного зовнішнього дефібрилятора для дорослого, дитини, немовляти. Критерії припинення реанімації. Післяреанімаційна підтримка. Допомога на воді: розпізнавання потопельника, наближення до нього, транспорту- 
вання до берега. Домедична допомога. Допомога при ураженні електричним струмом, блискавкою. Матеріально-технічне забезпечення заняття: манекен дорослого, дитини і немовляти для проведення базових реанімаційних заходів, автоматичний зовнішній дефібрилятор (навчальний), бар’єрні пристрої (в асортименті) для штучної вентиляції легень рот до рота, мішок АМБУ з комплектом лицевих масок, комплект рото- і носогорлових трубок, гумові рукавички. Практичні навички: діагностика раптової затримки кровообігу, техніка натискання на грудну клітку та штучної вентиляції легень, техніка застосування автоматичного зовнішнього дефібрилятора.

Тема 4. Кровотечі і їх методи зупинки. Колапс і шок - домедична допомога (4 год). Причини й ознаки зовнішньої кровотечі. Поняття про масивну зовнішню кровотечу. Причини й ознаки внутрішньої кровотечі. Техніка зупинки зовнішньої кровотечі: тиск на рану, тампонування рани, тиснуча пов’язка, піднімання кінцівки, спокій. Кровоспинні засоби на марлевій основі, техніка застосування. Техніка зупинки кровотечі при неефективності вищеперерахованих засобів: перетискання артерії на відстані. Показання і техніка накладання різних видів джгутів, імпровізованих закруток. Домедична допомога при внутрішній кровотечі. Поняття про колапс і шок, причини їх виникнення, розпізнавання і надання домедичної допомоги. Конкретні випадки: кровотеча з ран кінцівок, носа, рота, вуха, ампутація кінцівки. Кровозамінники та засоби для їх довенного введення на етапі домедичної допомоги. Підтримання температурного балансу. Матеріально-технічне забезпечення заняття: манекен для тампонування ран, манекен для катетеризації вени, джгути гумові кровоспинні, джгути типу CAT, SWAT, індивідуальні перев’язувальні пакети універсальні, марлеві та еластичні бинти, кровоспинні засоби на марлевій основі (навчальні), ізраїльські бандажі, кровозамінники, системи для переливання, термопокривала, гумові рукавички. Практичні навички: діагностика зовнішньої кровотечі, діагностика масивної зовнішньої кровотечі, діагностика і домедична допомога при внутрішній кровотечі, приблизна оцінка об’єму втраченої крові при зовнішній кровотечі, діагностика і домедична допомога при колапсі, діагностика і домедична допомога при шоці, послідовність зупинки зовнішньої кровотечі, техніка зупинки масивної зовнішньої кровотечі шляхом накладання джгутів різної конструкції, техніка зупинки масивної зовнішньої кровотечі шляхом тампонування рани, техніка венопункції і катетеризації вени, техніка переливання кровозамінників, техніка забезпечення температурного балансу з допомогою термопокривала.

Тема 5. Рани різної локалізації, ознаки, домедична допомога (2 год). Причини та ознаки ран м’яких тканин, проникаючих і непроникаючих ран черепа, грудної клітки, живота. Протекція ран м’яких тканин шляхом накладання пов'язок. Техніка накладання пов’язок при пораненнях черепа, ока, вуха, нижньої щелепи. Особливості поранення грудної клітки, поняття про пневмоторакс. Домедична допомога при відкритому і напруженому пневмотораксі. Специфіка пов’ язок при проникаючих пораненнях живота. Особливості пов’язок при наявності стороннього тіла в рані. Матеріально-технічне забезпечення заняття: індивідуальні перев’язувальні пакети універсальні, марлеві та еластичні бинти, манекен для пункції грудної клітки, табельні та пристосовані голки для пункції грудної клітки при напруженому пневмотораксі, табельні та пристосовані засоби для оклюзії грудної клітки при відкритому пневмотораксі, гумові рукавички, манекен для імітації травм, муляжі для імітації ран, штучна кров. Практичні навички: діагностика ран м’яких тканин, діагностика проникаючих ран, техніка накладання пов’язок на різні ділянки тіла, техніка пункції грудної клітки при напруженому пневмотораксі, техніка накладання різних видів оклюзійних пов’ язок, техніка накладання пов’язок при сторонньому тілі в рані.

Тема 6. Травми кінцівок. Больовий шок. Домедична допомога (2 год). Анатомічні особливості опорно-рухового апарату. Види травм кінцівок (розтягнення зв’язок, вивихи, переломи: відкриті i закриті), причини та ознаки. Абсолютні ознаки переломів. Транспортна іммобілізація табельними та пристосованими засобами. Особливості надання домедичної допомоги при відкритих переломах. Біль, причини, шкала болю. Боротьба з больовим шоком. Матеріально-технічне забезпечення заняття: манекен для імітації травм опорно-рухового апарату, індивідуальні перев’ язувальні пакети універсальні, марлеві та еластичні бинти, косинки, шини драбинчасті (в комплекті), шини “Sam Splint” в комплекті, шина “Kendrick”, пристосовані засоби для транспортної іммобілізації (набір дощечок), протибольові засоби для перорального та внутрішньом’язового застосування, ґумові рукавички. Практичні навички: діагностика травм суглобів, діагностика закритих переломів кісток 
різних анатомічних ділянок, транспортна іммобілізація різних пошкоджень за допомогою косинок, транспортна іммобілізація різних пошкоджень кінцівок за допомогою шин Крамера, Sam Splint, Kendrick, пристосованих засобів.

Тема 7. Травми голови, хребта і таза (2 год). Причини та ознаки травм голови, хребта та таза. Специфіка первинного і вторинного обстеження при травмах голови та хребта. Транспортна іммобілізація. Надання домедичної допомоги при дорожньо-транспортній пригоді (ДТП). Тактика рятувальника при ДТП. Специфіка первинного і вторинного обстеження. Екстрене виймання постраждалого з автомобіля. Матеріально-технічне забезпечення заняття: муляж травм голови, макет салону автомобіля, індивідуальні перев'язувальні пакети універсальні, марлеві та еластичні бинти, косинки, шийні комірці, довга транспортувальна дошка з головотримачем і лямками, іммобілізаційний жилет, термопокривало, гумові рукавички. Практичні навички: діагностика травми голови, хребта і таза, техніка стабілізації голови і забезпечення прохідності дихальних шляхів при травмі голови і хребта, техніка накладання шийного комірця, техніка вкладання на довгу транспортувальну дошку, техніка застосування іммобілізаційного жилета, техніка обстеження постраждалого в салоні автомобіля, техніка виймання постраждалого із салону автомобіля із використанням табельних засобів, техніка екстреного виймання постраждалого із салону автомобіля.

Тема 8. Опіки, відмороження, кліматичні ураження (2 год). Причини та ознаки дії високої температури (сонячний удар, тепловий удар, опіки), домедична допомога. Розпізнавання глибини і площі термічних опіків. Причини та ознаки дії низької температури (переохолодження, відмороження), домедична допомога. Дії кислот і лугів, домедична допомога. Специфіка допомоги при опіках очей різного походження. Матеріально-технічне забезпечення заняття: муляжі опіків та відморожень різної локалізації, індивідуальні перев'язувальні пакети універсальні, марлеві та еластичні бинти, косинки, термопокривало, табельний та пристосований пристрій для промивання очей, гумові рукавички. Практичні навички: розпізнавання і домедична допомога при термічних і хімічних опіках різної локалізації, розпізнавання глибини і площі опіків, діагностика і домедична допомога при тепловому i сонячному ударі, діагностика і домедична допомога при переохолодженні, діагностика відморожен- ня та його глибини, домедична допомога, техніка промивання очей табельними і пристосованими засобами.

Тема 9. Домедична допомога при невідкладних станах (2 год). Причини, діагностика і домедична допомога при зомлінні, комі невідомої етіології, судомах, болю у серці (стенокардія, інфаркт), інсульті, гострому болю в животі, отруєнні невідомою речовиною і невідомим газом, укусах комах, собак, змій. Матеріально-технічне забезпечення заняття: студентам симулюються невідкладні стани волонтерами. Проводиться первинне і вторинне обстеження. Надається домедична допомога. Застосовуються всі вищеперераховані засоби для надання домедичної допомоги. Практичні навички: розпізнавання і домедична допомога при зомлінні, комі невідомої етіології, судомах, болю в серці (стенокардія, інфаркт), інсульті, гострому болю в животі, отруєнні невідомою речовиною і невідомим газом, укусах комах, собак, змій.

Тема 10. Основи тактичної медицини. Домедична допомога при бойовій травмі (6 год). Принципи надання домедичної допомоги під вогнем, на етапі винесення з поля бою, в укритті. Організація та проведення медичного сортування при виникненні масових санітарних втрат. Алгоритм проведення медичного сортування. Медична інформаційна картка: призначення, правила заповнення. Організація та проведення переміщення (відтягування, винесення) пораненого в укриття у бойових (секторах обстрілу, укриття та евакуації) умовах. Підготовка поранених до евакуації. Медична евакуація. Організація надання допомоги під час транспортування в бойових (сектор укриття та евакуації) умовах. Матеріально-технічне забезпечення заняття: бронежилети, шоломи, тактичні окуляри, макети автоматів, індивідуальні аптечки. Практичні навички: виконуються відповідно до стандарту підготовки 01.305.001 “Підготовка військовослужбовця з військово-медичної підготовки”.

Тема 11. Підсумковий модульний контроль (2 год).

Важливе значення при роботі зі студентамиіноземцями має ефективне застосування мультимедійного супроводу. Фактично кожну практичну навичку можна представити на відео із звуковим супроводом, що можна створити самостійно або скористатися посиланнями в Інтернеті. Для пояснення окремих дій можна вивести на екран зображення окремих анатомічних ділянок тіла людини, схем тощо. Наш особистий досвід засвідчив потребу в алгоритмах з домедичної допомоги. Їх прикла- 
дом є дані із окремих вітчизняних посібників [1, 2]. 3 позицій мнемоніки, алгоритми, які розглядаються на занятті, повинні бути постійно візуально доступними для студентів, що вимагає створення відповідних плакатів.

Методично, заняття для студентів-іноземців 3 домедичної допомоги полягає у практичному показі тієї чи іншої навички, реалізації простого сценарію самим викладачем, який коментує кожну свою дію 3 наступним відпрацюванням подібних сценаріїв кожним студентом. Кінцеве оцінювання доречно зробити на основі ефективності та успішності роботи студентів за сценаріями та тестового опитування основного матеріалу теми. Для двогодинного заняття доцільно виділяти не більше 15 хв для

\section{Список літератури}

1. Домедична допомога (алгоритми, маніпуляції) : метод. посіб. / [В. О. Крилюк, В. Д. Юрченко, А. А. Гудима та ін.]. - К. : НВП “Інтерсервіс”, 2014. - 84 с. підсумкового тестування (12-15 тестів з вибором правильної відповіді).

Висновок. Викладання домедичної допомоги в екстремальних умовах для студентів-іноземців повинно відбуватися у спеціалізованих навчальних лабораторіях і вимагає грунтовного логістичного забезпечення. Заняття повинно проходити у формі виконання типових сценаріїв симульованих невідкладних станів. Кожну навичку викладач спершу показує самостійно, а далі пропонує виконати кожному студенту. Оцінювання відбувається на основі ефективності та якості реалізації студентом сценаріїв з невідкладного стану та тестового контролю.

2. Домедична допомога в умовах бойових дій : метод. посіб. / [В. Д. Юрченко, В. О. Крилюк, А. А. Гудима та ін.]. - К. : Середняк Т. К., 2014. - 80 с.

Отримано 02.09.15 